\title{
Measurement reliability of endotracheal tubes cuff pressure between industrial and handmade devices
}

\author{
Ennie Luana Melo Cunha', Roberta Duarte Sales', Zênia Trindade Souto Araújo', Girlene Camilo Gomes², \\ Ciro Leite Mendes², Heleodório Honorato dos Santos ${ }^{3}$, Simone dos Santos Maciel ${ }^{3}$
}

\begin{abstract}
Introduction: The cuff pressure is measured in industrial equipment, however, be valid in the craft equipment is still questioned. Objective: To evaluate the reliability of the measurement methods of cuff pressure endotracheal tubes with industrialized and handmade equipment. Method: Were analyzed 40 endotracheal tubes, two brands (Solidor ${ }^{\circledR}$ and Ruschelit ${ }^{\circledR}$ ) and different diameter $(8,0 \mathrm{~mm}$ and $8,5 \mathrm{~mm})$, inflated $20 \mathrm{~mL}$ of air in the pilot balloon with plastic syringe and $20 \mathrm{~mL}$, followed by pressure measurement device with industrial $\left(\mathrm{cmH}_{2} \mathrm{O}\right)$ and handmade device $(\mathrm{mmHg})$. After the conversion of $\mathrm{cmH} 2 \mathrm{O}$ values for $\mathrm{mmHg}$, the reliability and agreement of measurements were performed by intra-class correlation (ICC) and Bland-Altman tests, respectively, using SPSS (version 15.0) and adopting a significance level of $5 \%$ for all comparisons. Results: The data showed similarity between the different pressure equipment,

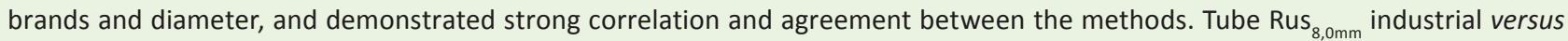
handmade ( $28.2 \pm 5.8$ vs $28.4 \pm 6.2 \mathrm{mmHg}$ : ICC=0.998; bias=0.20); Tube Solidor ${ }_{8.0 \mathrm{~mm}}$ industrial versus handmade $(75.9 \pm 1.1 \mathrm{vs} 76.4 \pm 1.2 \mathrm{mmHg}$ : ICC=0.878; bias=0.40); Tube Rus $_{8.5 \mathrm{~mm}}$ industrial versus handmade $(17.1 \pm 8.8$ vs $17.8 \pm 8.9 \mathrm{mmHg}$ ICC=0.999; bias $=0.67)$; Tube Sol ${ }_{8.5 \mathrm{~mm}}$ industrial versus handmade (78.7 \pm 4.7 vs $78.6 \pm 4.6 \mathrm{mmHg}$ : ICC=0.996; bias=-0.1). Conclusion: The high reliability and agreement presented in this study suggest that the cuff pressure gauge handmade can be used safely to evaluate the cuff pressure of the endotracheal tube.
\end{abstract}

Keywords: endotracheal intubation, trachea, Intensive Care Unit, reproducibility of results.

\section{INTRODUCTION}

An artificial airway consists of a tube, or tracheal cannula provided with an inflatable cuff(1-4), at the bottom end which in turn is connected to a balloon pilot, equipped with a spring tensioned valve and a connector that allows inflation and deflation ${ }^{(5)}$. The cuff has the function to ensure the proper pulmonary ventilation without allowing air leakage ${ }^{(3,6-8)}$, and prevent aspiration of oropharyngeal and gastroesophageal contents into the lungs $s^{(3,6-10)}$.

The pressure in the cuff is harmful to the tracheal mucosa ${ }^{(6,9-11)}$ especially when the pressure setting is not appropriate, using extremely safe values ${ }^{(9-11)}$. However, the air volume used to inflate the balloon must not generate higher pressure than the tracheal mucosa perfusion, only a "seal" pressure to enclose de air ${ }^{(7,10-12)}$.

Martins et al. ${ }^{(13)}$, call out attention to injuries arising from the insertion of an artificial airway, claiming that they are associated with a local trauma, extended remain, using inappropriate caliber tubes to the patient, and high cuff pressures.

According to Scanlan and Simmons ${ }^{(14)}$, these injuries are attributed to the fact that the artificial airway does not have the exact shape of the patient's anatomy, causing high pressure on the tissue, since the tracheal mucosa has an infusion pressure between 30 to $40 \mathrm{mmHg}^{(4)}$, and when higher pressures are enforced to the tracheal structures, we have as results ${ }^{(11,14)}$ : tissue ischemia, ciliary loss, bleeding, ulceration, tracheomalacia (softening of the tracheal cartilage), subglottic stenosis, and tracheoesophageal fistula $a^{(3,10,15)}$.

In this sense, Peña et al. ${ }^{(3)}$ argue that this pressure keep between 25 to $34 \mathrm{cmH}_{2} \mathrm{O}$ with a minimum limit of $20 \mathrm{cmH}_{2} \mathrm{O}$ to prevent air leakage and bronchoaspiration. Souza and Santana ${ }^{(16)}$ argue that the cuff should be kept inflated with an ideal pressure of 20 to $30 \mathrm{cmH}_{2} \mathrm{O}$, to prevent any bronchoaspiration, using a lower pressure, and damage to the tracheal wall, in the use of a higher pressure. However, there is no agreement to the maximum pressure value in the cuff of the endotracheal tube to avoid injury. To Castillo et al. ${ }^{(11)}$, the critical pressure value in the cuff have been considered from 25 to $39 \mathrm{cmH}_{2} \mathrm{O}$, near capillary perfusion pressure ${ }^{(11)}$, however, despite the knowledge of the complications that excessive pressure of the cuff causes and the necessity of it pressure checking, this routine is neglected in most hospital services ${ }^{(11)}$.

\footnotetext{
Corresponding author: Heleodório Honorato dos Santos. Av. Monsenhor Odilon Coutinho, 191, apto. 402 - Cabo Branco; João Pessoa, PB. Zip Code: 58045-120. E-mail: dorioufpb@gmail.com

3Professor of the Physiotherapy Department of the Federal University of Paraíba - UFPB, João Pessoa, Paraíba, Brazil.
}

Full list of author information is available at the end of the article.

Financial Support: nothing to declare

Submission date 19 January 2017; Acceptance date 03 March 2017; Publication date 29 March 2017 
Aranha et al. ${ }^{(6)}$, reveal that $83,2 \%$ of Intensive Care Unit (ICU) services do not routinely measure the pressure cuffs, and propose a quick and low cost maneuver to adjust these pressures using a digital pressure gauge graduated in $\mathrm{cmH}_{2} \mathrm{O}$ coupled to the syringe of $15 \mathrm{~cm}^{3}$, with graduation.

Nowadays, there are in the market industrial devices that are specific to measuring the pressures of the cuff, but hasn't been found in the scientific literature a research that has comparing the measurement of the endotracheal cuff pressure using industrial equipment and using a handmade device.

Thus, the aim of this study was to evaluate the reliability of the endotracheal tube cuff pressure measurement methods between industrial and handmade equipment.

\section{METHOD}

\section{Sample Characteristics}

Forty endotracheal tubes from two different brands (Solidor ${ }^{\circledR}$ - Well/Lead Medical Cd., Ltd/China; Rusch - Rüsch Ltd/Uruguay) with specific diameters $(8.0 \mathrm{~mm}$ and $8.5 \mathrm{~mm})$ were divided into four groups of ten tubes separated by brand and diameter, so they could be analyzed.

All tubes were subjected to a functional inspection, and the tubes remained in the study showed its components unchanged, lacerations or perforations cuff.

The instruments for measurement of cuff pressure used were an industrial analogical cufflator, graduated in $\mathrm{cmH}_{2} \mathrm{O}$ (VBM - Germany) and an analogical pressure manometer, graduated in $\mathrm{mmHg}$ (Premium - Brazil) attached to a three-way stopcock and to a $20 \mathrm{ml}$ syringe, which is the handmade cufflator. Both instruments were properly calibrated by Instituto de Metrologia e Qualidade Industrial da Paraíba (IMEQ-PB, Brazil), before the beginning of the research, based on the Instituto Nacional de Metrologia, Qualidade e Tecnologia (Inmetro) ordinance number 24, from February 22,1996 , about the standards of periodic calibration of the instruments.

\section{Procedures}

The data were collected at the IMEQ-PB laboratory, using the handmade and industrial cufflator as comparative measure procedure of the method of measurement of the cuff pressure of endotracheal tubes (Figure 1), through the following protocol: inflation of $20 \mathrm{ml}$ of air into the pilot balloon of the tube with a plastic syringe $(20 \mathrm{ml})$, followed by the measurement of the pressure through the analogical cufflator (VBM - Germany). After that, the balloon was completely deflated, then it was inflated again with $20 \mathrm{ml}$ of air and a new measure was made through the handmade cufflator (an analogical manometer graduated in $\mathrm{mmHg}$ and an inflatable pear - both from the sphygmomanometer Premium - connected to a three-way stopcock).
This procedure was repeated 10 times in each endotracheal tube and all the steps previously described were executed with both brands and diameter of tube, by one researcher.

At the end of the measurement and register of data, the values obtained were converted from $\mathrm{cmH}_{2} \mathrm{O}$ to $\mathrm{mmHg}$ (value in $\mathrm{cmH}_{2} \mathrm{O} \times 0.7355$ ) for comparison, since the instruments use different units of measurement.

\section{Statistical analysis}

The data were analyzed at the electronic spreadsheet Statistical Package for the Social Science (SPSS - 15.0 - IBM Corporation, USA), and the reliability and agreement of the measures was evaluated by the intra-class correlation (ICC) and Bland-Altman tests, respectively, using a significance level of $5 \%$ for all the comparisons.

The classification suggested by Santos et al. ${ }^{(17)}$, for the analysis of the ICC, was used: null $=0.0$; weak $=0.01$ a 0.3; regular $=0.31$ a 0.6 ; strong $=0.61$ a 0.9 ; very strong $=0.91$ a 0.99 ; and full $=1.0$.

\section{RESULTS}

The intra-class correlation test - ICC (Figure 2A) showed a strong correlation $(I C C=0.998, p<0.001)$ between the measures of the cuff pressure of the Rusch endotracheal tubes of $8.0 \mathrm{~mm}$, measured by the industrial cufflator $(28.2 \pm 5.8 \mathrm{mmHg})$ and the handmade cufflator $(28.4 \pm 6.2 \mathrm{mmHg})$. According to the Bland-Altman test (Figure 2B) that evaluated the difference between both methods of pressure measurement (industrial and handmade cufflator), it was observed a very low and without statistical significance bias (0.20), and the Upper Limit of Agreement (ULA=1.292) and Lower Limit of Agreement ( $L L A=-0.902$ ) of agreement point to a difference of $0.39 \mathrm{mmHg}$ between the two measurements.

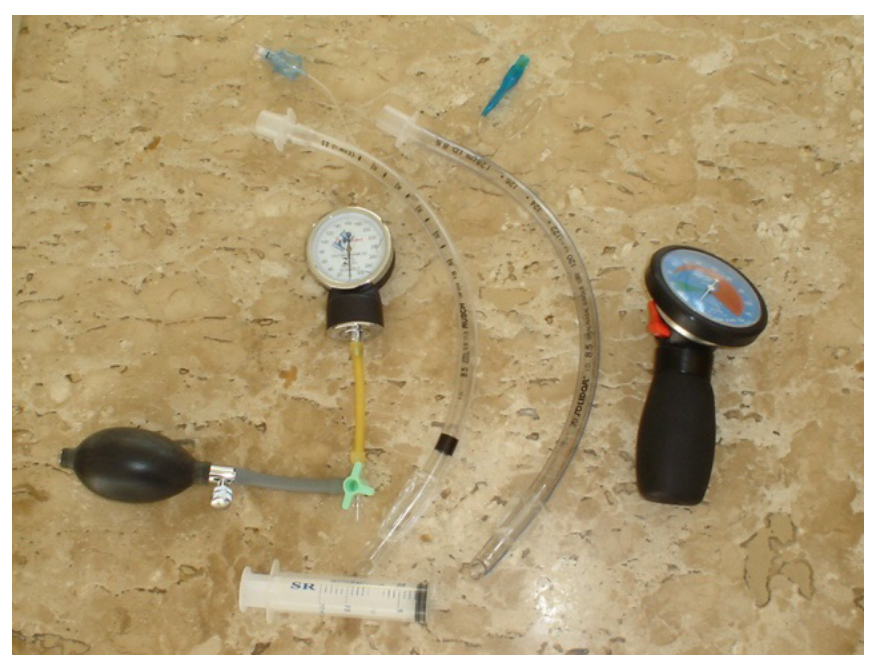

Figure 1 - Instruments used in the study: a) handmade cufflator; b) endotracheal tube; c) industrial cufflator 


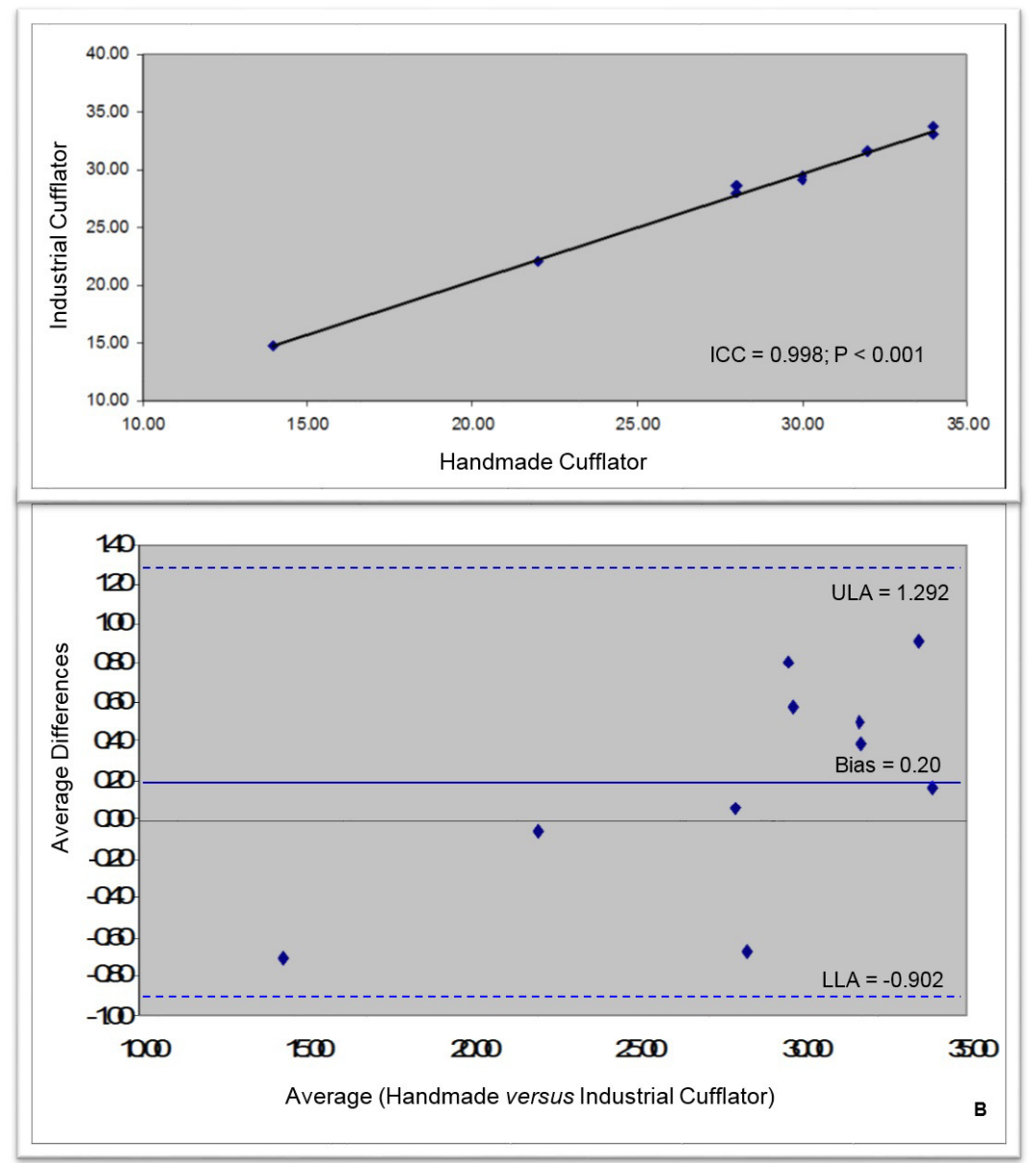

Figure 2 - Intra-class correlation (ICC) between handmade and industrial cuff pressure gauge (A) and Bland-Altman for differences and means of pressure measurements of the endotracheal tube Rusch $-8.0 \mathrm{~mm}$ (B). Legend: ULA=upper limit of agreement; LLA=lower limit of agreement

The measurements of the cuff pressure of the Solidor endotracheal tubes of $8,0 \mathrm{~mm}$ (Figure $3 \mathrm{~A}$ ), measured by the industrial cufflator $(75.9 \pm 1.1 \mathrm{mmHg})$ and the handmade cufflator $(76.4 \pm 1.2 \mathrm{mmHg})$ showed a strong correlation (ICC $=0.878 ; \mathrm{p}<0.002$ ). These measurements also showed good concordance, since the graphic of the Bland-Altman test (Figure 3B) also shows a low bias (0.40), and the Upper Limit of Agreement (ULA=1.869) and Lower Limit of Agreement (LLA=1.065) of agreement, showing a difference of $8.0 \mathrm{mmHg}$ between the two measures.

The comparison of the measures of the cuff pressure of the Rusch endotracheal tubes of $8,5 \mathrm{~mm}$ (Figure $4 A$ ) showed a very strong correlation coefficient $($ ICC $=0.999 ; p<0.001)$ for the variables industrial cufflator $(17.1 \pm 8.8 \mathrm{mmHg}$ ) and handmade cufflator $(17.8 \pm 8.9 \mathrm{mmHg})$, while the scatter diagram of the Bland-Altman test (Figure 4B) showed a low bias (0.67), with Upper Limit of Agreement (ULA $=1.734$ ) and Lower Limit of Agreement (LLA=-0.398) of agreement, showing a difference of $1.336 \mathrm{mmHg}$ between the two measures.

The comparison of the pressure of the Solidor endotracheal tubes of $8.5 \mathrm{~mm}$ (Figure $5 \mathrm{~A}$ ) between the measures of the industrial cufflator $(78.7 \pm 4.7 \mathrm{mmHg})$ and the handmade cufflator $(78.6 \pm 4.7 \mathrm{mmHg})$ also showed a very strong correlation coefficient (ICC=0.996; $\mathrm{p}<0.001)$. At the Bland-Altman graphic (Figure $5 \mathrm{~B}$ ) for evaluation of the methods concordance, the comparison between the measures showed a negative and low bias $(-0.10)$ and a small difference $(0.19)$ between the ULA of 1.015 and the LLA of -1.205 .

\section{DISCUSSION}

The reliability and consistency of the methods adopted on this study were determined by intra-class correlation coefficient (ICC) tests ${ }^{(17,18)}$ or reproducibility coefficient $(R)^{(17,18)}$ and Bland-Altman ${ }^{(19,20)}$, respectively. The latter provides a graph that lets you easily view and interpret the size and magnitude of differences in measurements, errors or outliers ${ }^{(21-23)}$. Through this tests can be determined the confidence interval to the average difference and the limits of agreement. The data presented indicate measuring error and may influence the clinical acceptability of the methods used ${ }^{(21-23)}$.

In the current study was demonstrated that beyond the existence of a very strong correlation coefficient 


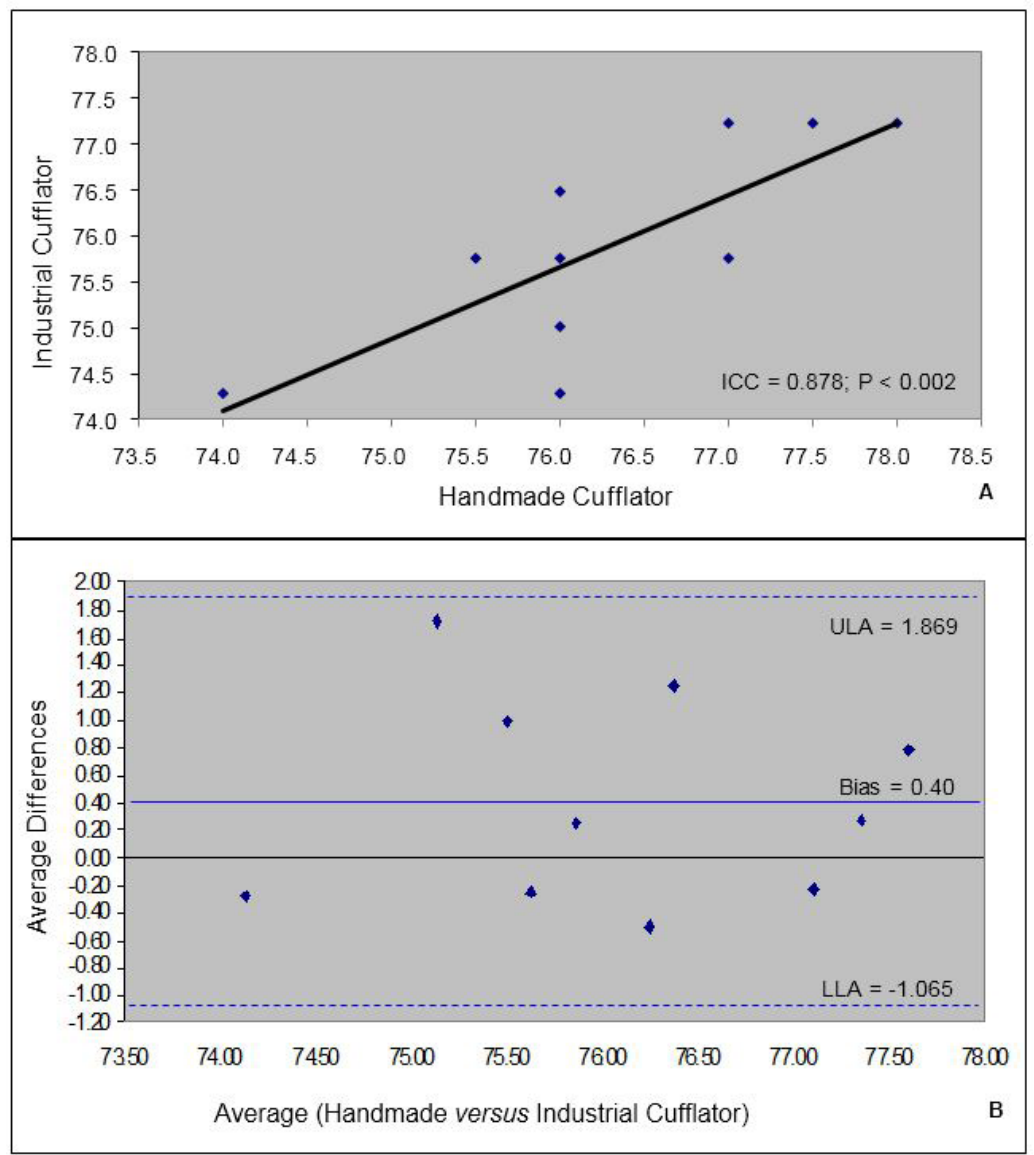

Figure 3 - Intra-class correlation (ICC) between handmade and industrial cuff pressure gauge (A) and Bland-Altman for differences and means of pressure measurements of the endotracheal tube Solidor $-8.0 \mathrm{~mm}$ (B). Legend: ULA=upper limit of agreement; LLA=lower limit of agreement

$(\text { ICC } \geq 0.91 \leq 0.99)^{(17,18)}$, between the checking methods of endotracheal cuff pressure, the Bland-Altman test ${ }^{(19,20)}$, by the low biases presented in both instruments, indicated high agreement between methods, and confirmed the benefit of practical use thereof.

The cuff pressure measurement of the endotracheal tube is a high importance procedure for prevention and minimization of complications associated with artificial airway institution ${ }^{(24) \text {, }}$ this in turn requires the use of a device developed specifically for this purpose, manometer and cuff gauge, methods considered safe and reliable ${ }^{(6,7,10,24,25)}$, data that corroborate with the results of this study. However, in recent study ${ }^{(26)}$, it is observed that in Brazil many hospitals do not have such device due to its high cost and the pressure is checked by indirect measurements.

Thus, the replacement of an instrument or other evaluation technique is only possible in case the new device is equivalent to the previous one and has to be tested prior to clinical use ${ }^{(27)}$. It is very unlikely that a measurement in two different clinical devices is exactly the same. Bland and Altman ${ }^{(28)}$, propose that the difference between the instruments be as small as possible in order to provide equivalent, accurate and reliable measurements ${ }^{(28)}$, confirming the results of this study.

The Agência Nacional de Vigilância Sanitária - ANVISA, Brazil( $^{(29)}$ sorts the specific device to measure pressure cuff as manometer and groups, in a single register, various gauges for various purposes. However, both the industrial and artisanal cuff gauge [also registered with ANVISA ${ }^{(29)}$ in gauge category] performs the same function: to measure a given pressure, suggesting that there are similarities and security in both equipments used for the measurement of this cuff study.

Several studies have showed that is not a routine of hospital services measurement the cuff pressure $e^{(3,6,7,11,12,25)}$ and researches show that the method of digital palpation of the external cuff is insufficient and ineffective to detect pressure changes $^{(3,7,19,11,25,30)}$.

The issue of poor compliance of cuff pressure measurements is something serious, among the causes observed for not gauging, the economic justification arises between them. The financial reality of public health services is very poor with a deficit of basic inputs. As raised by Freitas and Schramm ${ }^{(31)}$, in Brazil the social and regional disparities mean that the health needs vary, falling to the managers of health policies, 


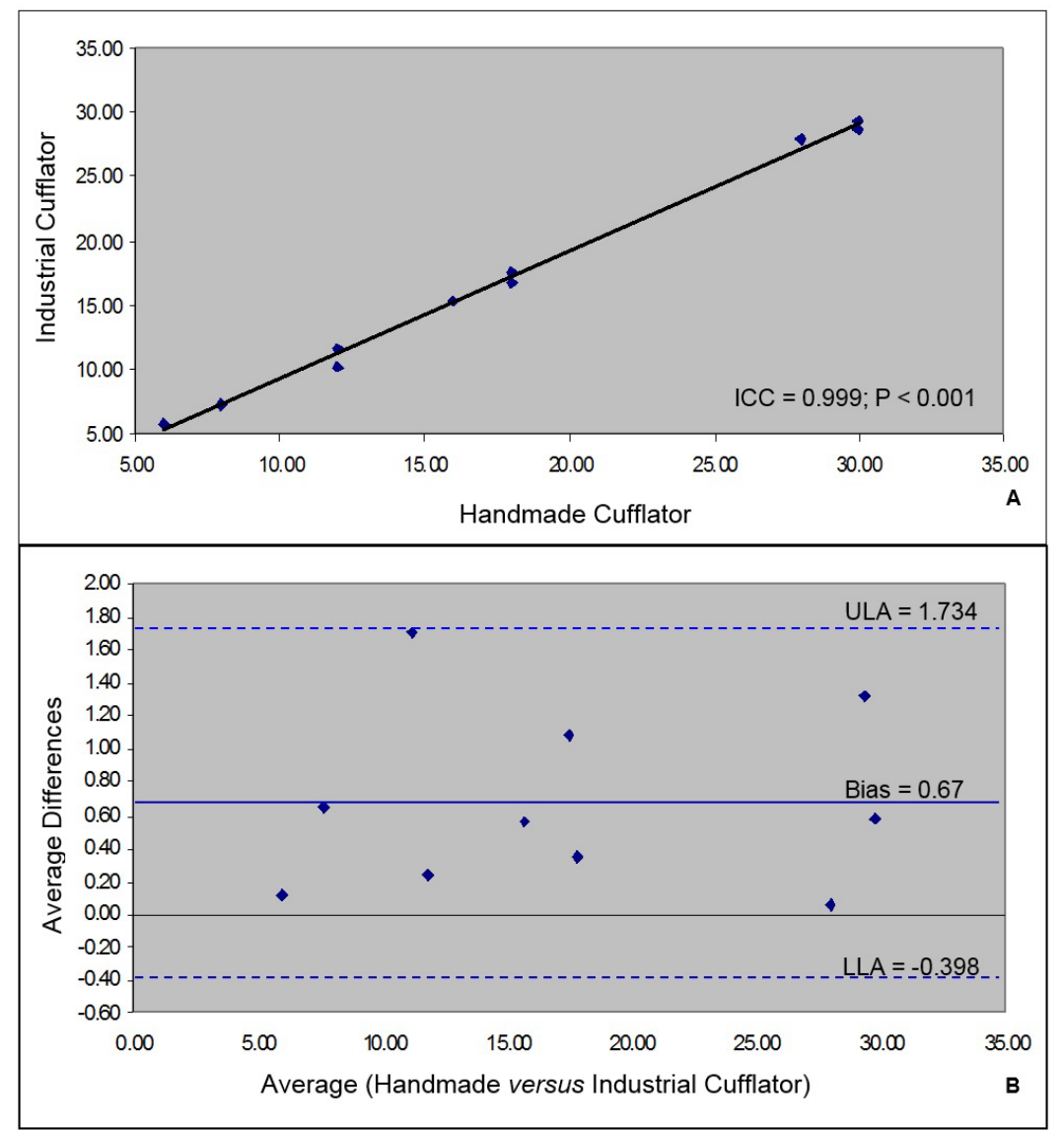

Figure 4 - Intra-class correlation (ICC) between handmade and industrial cuff pressure gauge (A) and Bland-Altman for differences and means of pressure measurements of the endotracheal tube Rusch $-8.5 \mathrm{~mm}$ (B). Legend: ULA=upper limit of agreement; LLA=lower limit of agreement

the responsibility of rationalizing the resources available $e^{(31)}$, since the high cost of a specific equipment to measure the cuff pressure can be a barrier to its acquisition. Thus, the handmade model could be an inexpensive cost-benefit in minimizing this lack of equipment and control cuff pressures.

Sultan et al. ${ }^{(27)}$ have shown that several factors influence the variation of the cuff pressure, as a change in tracheal muscles tonus, hypothermia, the patient position and also the cuff (27), reinforcing the need for frequent monitoring and adjustment of cuff pressure.

Some studies ${ }^{(32-34)}$ indicates that cuff inflation must be carried out until there is complete occlusion of the pathway and no air leaks. However, others ${ }^{(35,36)}$ show that it is essential to control the cuff pressure.

Annoni and Pires-Neto ${ }^{(26)}$ report that the technique that uses the syringe to measure the cuff pressure is not effective to keep the cuff pressure within the recommended limits and therefore is not safe. However, they claim that it is an alternative, cheap and fast method to ensure that this is neither too high to injure the trachea nor too low to avoid micro aspirations in hospitals where there is no specific manometer to perform such measurements.
However, the results of this study demonstrated through the Bland-Altman plots that practically there is no difference between the two methods of endotracheal tube cuff pressure from Rusch and Solidor brand with 8.0 and $8.5 \mathrm{~mm}$ of diameter, measured both by industrial gauge as the artisanal one, indicating a strong consistency in the allocation of both methods, suggesting recommendation of this measurement method.

The limitation of this study was the in vitro realization doesn't reproduce the cuff pressure variations that could involve on the mucosa of patients with artificial airway. Although, according to Ono et al. ${ }^{(37)}$, a simple change in the angle of the head causes changes in cuff pressure, the authors further state that the cough reflex and the swallowing reflex changed by the awareness are factors that alter the pressure of the cuff. Thus, the fact that study was conducted in vitro is a relevant limitation, because it couldn't introduce forms of control for many variables in an experiment in vivo. Another limitation is due to the fact that the data collection was not made by methodological "blind" design. In addition to methodological limitations is the fact of not having been assessed and calculated the existence of leakage in the 


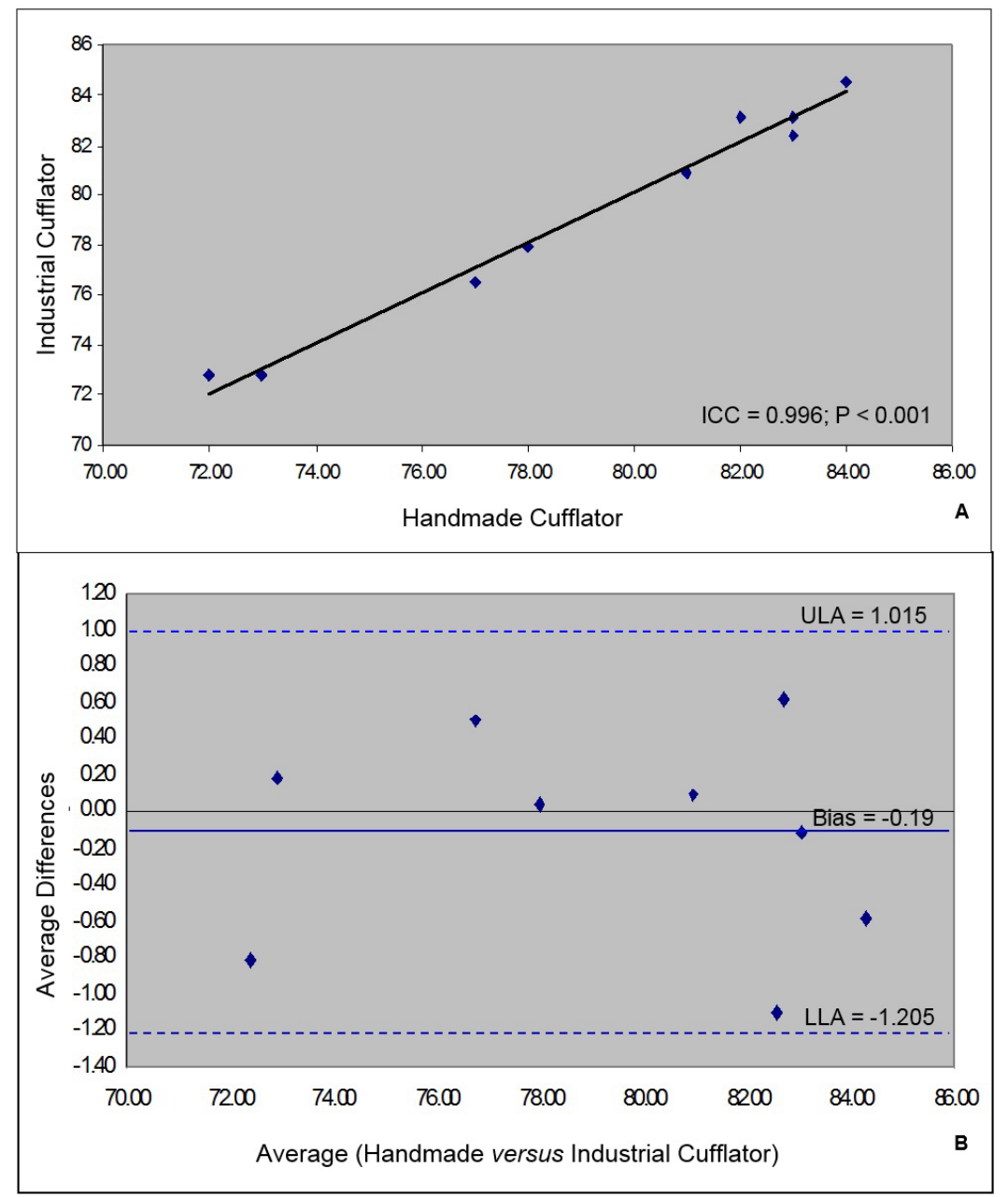

Figure 5 - Intra-class correlation (ICC) between handmade and industrial cuff pressure gauge (A) and Bland-Altman for differences and means of pressure measurements of the endotracheal tube Solidor $-8.5 \mathrm{~mm}$ (B). Legend: ULA=upper limit of agreement; LLA=lower limit of agreement

equipment built by hand besides not having been randomized the order of steps.

\section{CONCLUSION}

The high reliability and agreement presented in this study suggest that the cuff pressure gauge handmade can be used safely to evaluate the cuff pressure of the endotracheal tube, proving to be an useful and cost-effective tool in the Intensive Care Unit services.

\section{Acknowledgements}

To the Directors of the Instituto de Metrologia e Qualidade Industrial da Paraíba (IMEQ-PB, Brazil) for their collaboration on this research.

\section{AUTHORS' CONTRIBUTIONS}

ELMC: data collection and preparation of the manuscript; RDS: data collection and preparation of the manuscript; ZTSA: data collection and preparation of the manuscript; GCG: data collection and preparation of the manuscript; CLM: data collection and preparation of the manuscript; HHS: statistical treatment, preparation and revision of the manuscript; SSM: statistical treatment; preparation and revision of the manuscript.

\section{CONFLICTS OF INTEREST}

Nothing to declare

\section{AUTHOR DETAILS}

${ }^{1}$ Intensivist Physiotherapist of the Memorial São Francisco Hospital - HMSF, João Pessoa, Paraíba, Brazil.

2Intensivist Doctor of the Lauro Wanderley Universitary Hospital - HULW/ UFPB, João Pessoa, Paraíba, Brazil.

\section{REFERENCES}

1. Matsumoto T, Carvalho WB. Tracheal intubation. J Pediatr. 2007; 83(2 Suppl):S83-90.

2. Emmerich JC. Início e manutenção do suporte ventilatório. In: Emmerich JC. Suporte ventilatório: aplicação prática. Rio de Janeiro: Revinter; 2001, p.15.

3. Peña ELC, Gregori WM, Filho Piccinini L, Vieira JE, Mathias LAST. Determinação de volumes e pressões de balonetes de tubos traqueais insuflados com ar ambiente ou óxido nitroso. Rev Bras Anestesiol. 2004; 54(3):335-42. 
4. Cordeiro AMG, Shin SH, Fernandes ICOF, Bousso A, Troster EJ. Incidência e características endoscópicas de lesões das vias aéreas associadas a intubação traqueal em crianças. Rev Assoc Med Bras. 2004; 50(1):87-92.

5. Marfatia S, Donahoe PK, Hendren WH. Effect of dry and humidified gases on the respiratory epithelium in rabbits. J Pediatr Surg. 1975;10(5):583-92.

6. Aranha AGA, Forte V, Perfeito JAJ, Leão LEV, Imaeda JC, Juliano I. Estudo das pressões no interior dos balonetes de tubos traqueais. Rev Bras Anestesiol. 2003;53(6):728-36.

7. Stewart SL, Secrest JA, Norwood BR, Zachary R. A comparison of endotracheal tube cuff pressures using estimation techniques and direct intracuff measurement. AANA J. 2003; 71(6):443-7.

8. Penitenti RM, Vilches JIG, Oliveira JSC, Mizohata MGG, Correa DI, Alonso TRMB, Mathiazzi IC, Testa RS. Controle da pressão do cuff na unidade terapia intensiva: efeitos do treinamento. Rev Bras Ter Intensiva; 2010;22(2):192-5.

9. Dullenkopf A, Schimitz A, Frei M, Gerber AC, Weiss M. Air leakage around endotracheal tube cuffs. Eur J Anaesthesiol. 2004;21(6):448-53

10. Mendes FF, Hintz L, Bredemeier Neto F. Volumes e pressão do balonete do tubo traqueal para oclusão da traquéia. Rev Bras Anestesiol. 1996;46(2):103-6.

11. Castilho EC, Braz JRC, Catâneo AJM, Martins RHG, Gregório EA, Monteiro ER. Efeitos da pressão limite $(25 \mathrm{cmH} 2 \mathrm{O})$ e mínima de "selo" do balonete de tubos traqueais sobre a mucosa traqueal do cão. Rev Bras Anestesiol. 2003;53(6):743-55.

12. Vyas D, Inweregbu K, Pittard A. Measurement of tracheal tube cuff pressure in critical care. Anaesthesia. 2002; 57(3):275-7

13. Martins RHG, Dias NH, Braz JRC, Castilho EC. Complicações das vias aéreas relacionadas à intubação endotraqueal. Rev Bras Otorrinolaringol. 2004; 70(5):671-7.

14. Scanlan CL, Simmons K. Tratamento das vias aéreas. In: Scanlan CL, Wilkins RL, Stoller JK. Fundamentos da terapia respiratória de Egan. São Paulo: Manole. 2000. p. 609-49.

15. Medalha S, Oliveira LC, Godoy I. Avaliação da pressão no balonete das cânulas endotraqueais e de traqueostomia em pacientes na Unidade de Terapia Intensiva. Rev Bras Terap Intensiva. 1999; 11(3):90-3

16. Souza CR, Santana VTS. Impacto da aspiração supra-cuff na prevenção da pneumonia associada à ventilação mecânica. Rev Bras Ter Intensiva. 2012; 24(4):401-6.

17. Santos $H H$, Hanashiro DN, Ávila MA, Camargo PR, Oliveira AB, Salvini TF. Efeito do treino isocinético excêntrico sobre a razão I/Q do torque e EMGs em sujeitos saudáveis. Rev Bras Med Esporte. 2014; 20(3):227-32.

18. Lin LI. A concordance correlation coefficient to evaluate reproducibility. Biometrics, Washington, D.C. 1989; 45(1):255-68.

19. Bland JM, Altman DG. Measuring agreement in method comparison studies. Stat Methods Med Res. 1999; 8(2):135-60.

20. Hirakata VN, Camey AS. Análise de concordância entre métodos de BlandAltman. Rev HCPA. 2009; 29(3):261-8.
21. Cardoso JR, Boer MC, Oliveira BIR, Kawano MM, Carregaro RL. Confiabilidade intra e interobservador da mensuração do ângulo de flexão anterior do tronco pelo método de Whistance. Fisioter. Pesqui. 2007; 14(3):44-9.

22. Hui SS, Yuen PY. Validity of the modified back-saver sit-and-reach test: a comparison with other protocols. Med Sci Sports Exerc. 2000; 32(9):1655-9.

23. Cardoso JR, Azevedo NCT, Cassano CS, Kawano MM, Ambar G. Confiabilidade intra e interobservador da análise cinemática angular do quadril durante o teste sentar e alcançar para mensurar o comprimento dos isquiotibiais em estudantes universitários. Rev Bras Fisioter. 2007; $11(2): 133-8$.

24. Camargo MF, Andrade APA, Cardoso FPF, Melo MHO. Análise das pressões intracuff em pacientes em terapia intensiva. Rev Assoc Med Bras. 2006; 52(6):405-8.

25. Braz JRC, Navarro LHC, Takata IH, Nascimento Jr P. Endotracheal tube cuff pressure: need for precise measurement. São Paulo Med J. 1999; 117(6):243-7.

26. Annoni R, Pires-Neto RC. Ineficácia da técnica de alívio de pressão por meio de válvula em insuflar o cuff. Rev Bras Ter Intensiva. 2014; 26(4):367-72.

27. Sultan P, Carvalho B, Rose BO, Cregg R. Endotracheal tube cuff pressure monitoring: a review of the evidence. J Perioper Pract. 2011; 21(11):379-86.

28. Bland JM, Altman DG. Statistical methods for assessing agreement between two methods of clinical measurement. Lancet. 1986; 1(8476):307-10.

29. Agencia Nacional de Vigilância Sanitária. Consulta de Produtos para a Saúde. Disponível: <http://www7.anvisa.gov.br/datavisa/Consulta_ Produto_correlato/rconsulta_produto_detalhe.asp> Acesso em 16 de fev. 2015.

30. Navarro LHC, Braz JRC, Pletsch AK, Amorim RB, Módolo SNP. Estudo comparativo das pressões dos balonetes de tubos traqueais contendo ou não válvula reguladora de pressão de Lanz. Rev Bras Anestesiol. 2001; 51(1):17-27.

31. Freitas EEC, Schramm FR. A moralidade da alocação de recursos no cuidado de idosos no centro de tratamento intensivo. Rev Bras Ter Intensiva. 2009; 21(4):432-6.

32. Passos E, Castilho VG. Papel da enfermagem na assistência ao paciente em ventilação mecânica. J Pneumol. 2000; 26(Supl. 2):27-34.

33. Barbosa PMK, Santos BMO. Determinação do volume de ar no "cuff" de sondas endotraqueais. Rev Bras Enferm. 1996; 49(2):225-38.

34. Burns SM, Shasby DM, Burke PA. Controlled pressure cuffed endotracheal tubes may not be controlled. Chest. 1983; 83(1):158-9.

35. Tu HN, Saidi N, Lieutaud T, Bensaid S, Menival V, Duvaldestin P. Nitrous oxide increases endotracheal cuff pressure and the incidence of tracheal lesions in anesthetized patients. Anesth Analg. 1999; 89(1):187-90.

36. Willis BA, Latto IP, Dyson A. Tracheal tube cuff pressure: clinical use of the cardiff controller. Anaesth. 1988;43(4):312-4.

37. Ono FC, Andrade APA, Cardoso FPF, Melo MHO, Souza RN, Silva GHC, Vieira BEM. Análise das pressões de balonetes em diferentes angulações da cabeceira do leito dos pacientes internados em unidade de terapia intensiva. Rev Bras Ter Intensiva. 2008; 20(3):220-5. 